\title{
A Review on the Economic Instability and Derivative Market of Pakistan
}

\section{Sadia Perveen}

Lecturer, Federal Urdu University of Arts Science and Technology, Karachi, Pakistan

Masood Ahmed

Associate Professor, Government College of Commerce and Economics, Karachi, Pakistan

Rukhshinda Begum

Lecturer, Department of Commerce, University of Karachi,

Karachi, Pakistan

\section{Doi:10.19044/esj.2018.v14n22p13 URL:http://dx.doi.org/10.19044/esj.2018.v14n22p13}

\begin{abstract}
This study covers the different problems of derivative market in Pakistan. Economic instability is the main constraint of derivative market in Pakistan. Due to instable economic conditions and restricted environment, corporate sector has not reflected significant participation in derivative market of Pakistan. Lack of infrastructure, political instability, ineffective governance, inexperience and unaware market participants are the other problems of Pakistan derivative market. Hence, literature is reviewed and analyzed due to unavailability of appropriate data for this study. Findings of the study have suggested that derivatives are an effective risk mitigating tool on one hand whereas on the other side, highly speculative activities in derivative market may be harmful for the financial markets and economic growth. In Pakistan perspective, all the players of financial market have adopted adequate risk mitigating strategies to avoid any adverse market scenario. Speculative activities are highly restricted due to economic instability as Pakistan is not in a position to absorb any financial shocks or crisis. The main regulatory authorities of this particular market are State Bank of Pakistan (SBP) and Security and Exchange Commission of Pakistan (SECP). These regulators are keenly observing market and taking necessary actions to prevent any adverse conditions. However, in developing economies these complex instruments create new risks which are badly affecting the whole economy.
\end{abstract}


Keywords: Derivatives, Economic Instability, Developing Economies, Pakistan.

\section{INTRODUCTION}

Derivatives are the financial instruments and value of the same is derived from the value of underlying asset at a particular point in time. Many developed countries use these instruments to reduce market risks. Common types of derivatives are future, forward and options.

Developed economies are heavily relying on their financial markets. Growth of financial market has positive relationship with economic growth. Financial markets of developed economies are using derivative tools to minimize the risk of market participants. However in developing economies the situation is adverse because of volatile environment.

The most important issue of developing economies is to bring hedging products in their markets to attract investors.

In case of Pakistan, the economy has seen severe ups and downs. If the economy of Pakistan is compared to the economies of other developing nations, we can observe that Pakistan has been unable to sustain solid growth. There are many reasons behind this slow growth. However, some important ones are:

1. Inconsistent economic policies

2. Political instability

3. Ineffective governance

4. External intervention

Over the last 10 to 15 years many developing countries strengthen their financial markets to achieve sustainable growth. The prominent financial market participants in Pakistan are the stock markets, non-banking financial institutions and banking institutions. Products related to equity derivatives were initiated in 2001 in the Karachi stock exchange. Single Futures deliverable in a month was the first that introduced. Several DFIs, NonBanking Financial Institutions and Mutual Funds are involved trading in derivatives market. SBP is the ultimate authority to supervise these DFIs and banks engaged in derivative transactions. Derivative transactions those are allowed at present under SBP regulations include:

- Foreign currency options,

- Forward rate agreements

- Interest Rate swaps

Various developing economies used derivatives to develop their financial markets for improving their economic conditions. In case of Pakistan, the situation is more critical due to economic instability, lack of investment, decline in net foreign assets and increase in domestic and foreign 
loans. All these factors are influencing the growth of derivative market in Pakistan.

Different products are being offered by the stock exchanges of Pakistan. These are:

Ready Market is a conventional stock market i.e. also known as the usual market where sellers and buyers come to trade shares.

Cash Settled Futures are standardized contracts, to buy or sell a n specific underlying instruments on a specific date in future, at an agreed price. All settlements are executed in cash with in 30,60 and 90 days from the date of the contract purchased.

Stock Index Futures are another product that is traded in stock exchanges. Each contract is to buy or sell a fixed value of the index. These contracts are settled in 90 days from the date of the contract.

Deliverable Futures are the forward contracts to buy or sell specific underlying instruments with actual delivery of underlying instrument. These are settled within 30 days after the contract is purchased.

Economic instability in Pakistan is the major challenge in growth of derivative market. This paper discusses that how the economic instability affects on derivative market growth and identifies factors which influence more in development of derivative market in Pakistan. As a developing economy, financial market in Pakistan comes across with various problems. These problems are tried to be discussed in this paper. This study is aimed to help understand the relationship of economic growth and derivative market in Pakistan.

\section{LITERATURE REVIEW}

The financial literature is quite rich related to risk reducing products and macroeconomic conditions. However, few studies have been conducted with respect to the impact of economic instability on derivative market in Pakistan. Hence, a literature gap still exists there. Now, empirical studies conducted in the above mentioned area are being briefly reviewed as follows.

Lourdes Trevino (2005) discussed the complexity of derivative instruments in relation with developing and developed economies. He concluded that derivative instruments have become more refined in their type and application. As per the study, concentration was observed towards Financial Derivatives. Moreover, exchange traded derivatives seemed to be preferred relative to the ones being traded Over the Counter (OTC). Derives were not only found to be the hedging strategy only rather supported for the growth of Capital Markets.

Keith Sill (1997) examined the contribution of derivatives in economic development. The result of study revealed that Derivatives provide support for the effective risk allocation. They are helpful in utilizing investment 
opportunities for firms as well as the individuals. Derivatives also help in market stability by making the investors and participants more informed.

Apanard (Penny) Prabha, Keith Savard and Heather Wickramarachi (2014) examined the derive market after the financial stress with the discussion from various stakeholders of Milken Institute. During the crisis and its outcomes, over the counter derivatives specifically credit derivatives condemned to be a cause of counterparty risk that required substantial change in regulations. They have observed significant differences of the effects of these derivatives pre and post crisis period. Roxana Angela Calistru and Carmen Castuleanu (2011) discussed the impact of derivatives on market functioning during normal and crisis conditions. During normal conditions, derivatives help support reducing risk and improving market liquidity whereas under the condition of stress and crisis, they cause increase uncertainties in valuation. Nevertheless, most of the economists have not paid required attention towards the same at macro level that is required to be addressed.

Aali-Bujari, Alí Venegas-Martínez, Francisco Pérez-Lechuga and Gilberto (2015) have covered six major economies of the world including the European Union, Japan, India, China, Brazil and the United States to examine the relationship between derivatives (independent variable) and the growth of economies (dependent variable). Analysis was based on the data collected for fourteen years and positive relationship was found between dependent and independent variable.

Ronald Dod (2002) analyzed the use of derivatives for transferring capital towards developing economies. Moreover, redistribution of risks is also studied in detail to help reduce the influence of disturbances in financial sector on the whole economy.

Juraj Lazový and Juraj Sipko (2014) studied the influence of financial derivatives on the real economy during the period from 1986 to 2012 . Over the counter as well as the exchange traded derivatives observed to be the vital factor in enhancing unemployment. However, both were found to play positive role in reducing inflation. However, they have mentioned the need of further research to verify the results of the study.

Market-based measures of expectations are similar to survey-based forecasts although the Market-based measures somehow provides more accurate predictions of the responses of financial market to data surprises as compared to the survey-based forecasts. Little evidence was found for the role of risk to drive a block between prices and probabilities in the market. (Refet S. Gurkaynak and Justin Wolfers, 2005)

Besides banks and financial institutions to reduce credit risk, credit derivatives were also used by the speculators to make money. Use of the credit derivatives for speculative purposes caused increase OTC trading and financial instability. Hence, a most comprehensive system for the use of credit 
derivatives should be designed to enhance their positive usages and related outcomes. (Roxana Angela Calistru, 2012).

Audrey Nguema Bekale, Erika Botha and Jacobus Vermeulen (2015) studied the trading of derivatives and its impact on the economic growth \& volatility in the economies of African countries. Though, local trading of derivatives has not proved to have a significant impact on economic growth. However, they have suggested further research in this area.

Derivatives helped improve the flow of capital by locking in asset prices and mitigating credit risks. Derivatives became famous after 1970 and growth in the variety of instruments made them complex too in the recent era. They have brought innovative changes in the financial world. (Dr. Priyanka Saroha and Dr. S.K.S. Yadav, 2013).

Yu-Kyung Kim and Freshia Mugo-Waweru (2011) studied the factors following the success of derivatives in developing Asian economies. Findings of the study revealed that spot market volatility, size of the underlying spot market and the market liquidity have significant positive effects on the trading volume of derivatives. Besides, Options are more successful relative to the Futures in terms of trading volume that may be due to the associated costs with the margin requirements

Derivatives are the recent observable fact in India. Hence, Indu Gautam and PC Kavidayal (2016) made an attempt to discuss the development and future of the derivative Market in India. They have also reflected the present state of derivative market in India respective to this global era. Objective of these attempts is to enhance the trust of Investors on the capital market of India. They have suggested the participation of government agencies to address problems prevailing in the derivative market. Banikanta Mishra, Sarat Malik and Laltu Pore have studied the influence of derivative trading on price discovery in India. They have found that extensive work has not been done in this area.

Earlier studies have shown positive relationship in equity market and economic growth of developing countries. However results of the research executed by R. David McLean, Jeffrey Pontiff and Mengxin Zhao (2017) did not provide evidences in support of earlier studies and theories. They are of the opinion that liberalization of equity market does not result in the growth. However, if such a situation is apparently reflecting then it may be through an indirect channel that has not been addressed in the earlier studies.

The growth of derivatives market has been observed in all related areas including exchange traded, over the counter, currency, commodity, interest rate equity and credit. Derivatives are very useful instruments in mitigating risk and are highly leveraged too. This leverage attracts the speculators and may cause unfavorable movements in price. Combination of leverage and 
volatility in these instruments require investors and policy makers to have a quite clear understanding for the same. (Rangarajan K. Sundaram, 2012)

Geert Bekaert and Campbell R. Harvey (2002) mentioned research areas that are ready to be explored. They state that the condition in the developed economies like USA is more aligned with the theories as these are the most efficient markets of the world. However, the task is challenging while doing the same for developing economies.

Derivative markets seemed to have grown in developing economics due to the increased financial and economic risks. Derivatives add development of these emerging economies through better management of these risks. (Saif Rahma and M. Kabir Hassan, 2011). Appropriate use of Derivative result in mitigating risks (systematic and non-systematic risk). Though, investors are of the view that securities with high risk result in the higher return. However, they want to keep the risk at minimum level. Nevertheless, derivatives market in Pakistan is underutilized mainly due to the information restraints and low liquidity in market. (Ali Raza M.Shafi, Syed Shabib ul Hassan and Ayesha Fareed, 2014)

Faiza Sajjad, Umara Noreen and Khalid Zaman (2013) examined the risks associated with the financial sector in Pakistan and role of derivatives in reducing the same. Findings of the study disclose that derivatives are an imperative source of mitigating risk, improving liquidity and required capital mobilization in economy.

Ahmad. M. Khalid (2007) discussed the problems of macroeconomic environment of Pakistan which affect the independent monetary and exchange rate policy. The study concluded that Pakistan is still unable to meet macroeconomic stability even after the progress made during some previous years. Hence, it is an appropriate time to design and implement new policies to reduce fiscal imbalances.

Rizwana Bashir, Rabia Shakir, Badar Ashfaq and Atif Hassan (2014) discussed the relationship between spot and forward exchange rates. They have concluded that the foreign exchange market of Pakistan is still in the initial phase of development and need considerable revision and improvement in policies to attain market efficiency.

Safi Ullah Khan and Zaheer Abbas (2013) studied the effects of derivative market on systematic risks in the equity market of Pakistan. They have focused on the futures market for stated purpose. They have stated that behavior of these futures in Pakistani market is different from that of the US. This difference was attributed to various factors including trading activities, methodologies to capture the effects of bear and bull markets of Beta and structure of the markets in developed \& developing economies.

Hussnain Ilyas (2015) analyzed the effects of structural changes as a result of political instability on the Karachi Stock Exchange. They have 
suggested a better law and order situation and significant policy changes for improvement in capital market.

However many economists and financial experts has researched the impact of derivatives on macroeconomic environment and conclude that it works in normal economic situation. In times of stress derivatives create an adverse impact on financial markets.

\section{METHODOLOGY}

This study is based on collection and analysis of secondary data through the review of earlier studies in this context because there is little data available regarding the derivative market of Pakistan. The main sources of this study are websites and publications of SBP, AKD, SECP, KSE and CDC. Furthermore, related literature is also reviewed to fulfill the objectives of this study. In addition, to understand the current scenario of Pakistan derivative market, interviews have been conducted with the officials of SBP, SECP, CDC and commercial banks.

\section{DISCUSSION AND ANAL YSIS}

Derivatives are complex financial instruments which have used in developed markets for risk management. However in developing economies like Pakistan derivative markets are still in progress. Capital market of any country provides a base of economic growth. If a country's economy has been growing than the financial institutions of this economy also strengthen and play a positive role to accelerate economic growth. The primary role of capital market is to provide a place in the economy where longer term loan able funds may be available. (Nadeem Naqvi, 2013).

The derivative market in Pakistan was established in 2002 and was introducing single stock deliverable futures. Later on, various other derivative instruments were introduced in Pakistan equity market. Derivatives are the financial innovation and many emerging economies use it to reduce risk and provide safeguard to their investors. Market participants in derivative markets are taking highly speculative positions to transfer their risk. Pakistan's equity market has seen many ups and downs in recent past years which restricted the investors as well as regulatory authorities. Some of these changes have occurred due to political and economic instability and some due to bad governance and less awareness about the market risks and financial products. The market participants are taking speculative positions which create more volatility, in addition economies like Pakistan cant affords these types of speculations. Regulatory authorities has played an important role in this scenario SECP formulated the rules and regulations regarding risk aversion products, as well as the formation of NCCPL is a great success to regulate the derivative market of Pakistan. Furthermore SECP also working on introduce 
new financial products in the market to improve country's economic conditions and it is proved that Stock exchanges are the parameter which uses to measure economic growth of a country. A well performed stock exchange with diversified portfolio opportunities attracts the investors as well. In Pakistan's case regulatory bodies of stock market and commodity market played a significant role to improve risk reducing products and facilitate market participant too. Our stock exchanges also failed to attract the foreign investors.

We can measure the economic growth of the country with economic activities perform in a certain period, however in case of Pakistan the GDP growth rate was declining during 2008 to 2013. In 2008 the GDP was $4.99 \%$, in 2009 was $0.36 \%$, in $20102.58 \%$, in $20113.66 \%$ and in 2012 was $4.36 \%$. The declining trend in GDP has been caused due to political instability, fiscal deficit, and excess government borrowings from domestic and international markets and trade deficit. We have seen the consequences of these problems on stock exchange as well, from 2010 to 2013 the number of new listed companies are 6 in 2010, 4 in 2011, 4 in 2012 and 3 in 2013. Decrease in FDI and FPPI also indicate the distrust of foreign investors.

It is observed that financial experts and bankers have a consensus on Pakistan derivative market is a small market with lots of problems such as inconsistent policies, law and order situation, uneducated market participants, and political instability. All these factors contribute to weaker economic conditions of Pakistan. However under this uncertain and discouraging conditions financial sector of Pakistan work efficiently. Financial experts and bankers agreed on the significant role of country's central bank and SBP played a great role to control the financial sector of Pakistan. Additionally, the country like Pakistan is not ready to expand their derivative market due to economic and external pressures. Currently SBP have allowed 6 institutions as Authorized Derivative Dealers namely 1.CitiBank 2.Deutche bank 3. Faysal Bank Limited 4.Habib Bank Limited 5. Standard Chartered Bank 6.United Bank Limited. All these banks are working in highly controlled derivative market as per SBP instructions and back to back hedge the derivative transaction is necessary to reduce their risk. Institutions are strictly prohibited to participate in speculative activities. The main problem of derivatives transaction is liquidity, in this regard SBP restrict the banks to maintain minimum paid capital requirements and BASELL 3 will introduce in current year. Furthermore that economic grounds of Pakistan are not sound, inflation, devaluation of PKR, highly speculative environment and lack of professional knowledge are the major troubles for growth of domestic market. In this regard SBP takes corrective measures on regular basis to prevent financial sector as well as economic breakdown. 
The derivative market is comprised of $70 \%$ of the total trading volume in India. Whereas, it is less than 5\% of the total trading volume in Pakistan even if deliverable future market is included, it is less than $10 \%$ (Nadeem Naqvi, 2013). Majority of the investors in this market are individuals and small investors whereas participation of institutional investors, banks, NBFC's and companies is very low. Single stock deliverable futures remained the famous instrument. Other instruments like cash settled futures and index futures are traded minimally. ( Pakistan Equity Derivative market. 2012)

Bhatia (2012) stated that high leverage has been offered by future markets trading which considered an advantage normally. However the in experienced trader might find that high leverage can be disadvantage; leverage magnifies losses as well as profit. Derivatives also lead to speculation due to leveraging which raises volatility in the markets. Derivative markets in developing economies create a complex situation.

Beakaert and Harvey (2003) considered the case of Pakistan and revealed that growth of real GDP has declined and real investment became negative after liberalization. Besides, Beakeart and Harvey (1997) explained that Pakistan is the only emerging market for which volatility has greatly increased after liberalization.

There are many economic advantages of using derivatives. Derivatives are effective risk mitigating tool. Future price discovery, increase the savings and investment in long run and provide investment opportunities are the benefits to use derivatives. However, it has also some drawbacks which are increase in volatility, rises new risks, increase in speculative positions and can leads the financial crisis.

Sometimes the future prices affect the spot market prices and if the prices will change at the time of exposure than will result market disruption. Similarly if any participant in the market will default than the entire participant of the market will have paid the cost. Many economist and institution have agreed on that the major cause of financial crisis of 2008 was exponential derivative growth. This financial crisis had not affected Pakistan capital markets directly due to highly controlled environment.

\section{CONCLUSION}

Derivatives are complex financial products which are being used to reduce risk. Derivatives have many economic benefits which are future price discovery, low cost, high leverage, and less market volatility. In developed economies these derivative products are commonly used as well as many emerging economies also using it to reduce their risk.

In Pakistan derivative market has been facing many problems such as political and economic instability, fiscal and trade deficit, weak market infrastructure, and inexperienced and uneducated market participants. 
Pakistan derivative market was started in 2001 and after that it has faced many ups and downturns. Financial institutions participation is very low in derivative market due to strict rules and regulations by SBP. Economic conditions of the country are the main problem in derivative market growth. Developing economies have faced many economic problems due to these regulatory authorities like central banks have taken the secure positions and feared to enter in derivative contracts. Many economists have agreed on that, the global financial crisis mainly caused by derivative products.

The financial crunch of 2008 has not directly affected Pakistani markets due to strict rules and measures taken by SECP and SBP after the crisis of 2005. Study findings suggest that derivative market help in economic growth if properly engaged and properly documented. However it also creates new risks in developing economies. This study concludes that economic instability is the main stumbling block in growth of derivative market in Pakistan.

As a policy indication we suggest that:

$>$ SBP and SECP should make necessary arrangements to educate participants about these complex instruments because the derivative market in Pakistan has a great potential but highly speculative activities may be harmful.

$>$ SECP should improve the market infrastructure and facilitate investor to be comfortable with this market. The formation of NCCPL, PMEX is a good measure to establish the derivative market.

> SECP should also work on Shariah compliance and should introduce Islamic mode of derivatives.

$>$ Market should be highly regulated to prevent undesired results by regulatory authorities.

\section{References:}

1. (n.d.). Retrieved from www.sbp.org.pk

2. (n.d.). Retrieved from www.secp.org.pk

3. (n.d.). Retrieved from www.kse.pk

4. Alí, A.-B., Francisco, V.-M., \& Gilberto, P.-L. (2016). Impact of derivatives markets on economic growth in some of the major world economies A difference-GMM panel data estimation (2002-2014). The IEB International Journal Of Finance, 110-127.

5. Bashir, R., Shakir, R., Ashfaq, B., \& Hassan, A. (2014). The Efficiency of Foreign Exchange Markets in Pakistan: An Empirical Analysis. The Lahore Journal of Economics , 19 (1), 133-149.

6. Bekaerta, G., \& Harvey, C. R. (n.d.). Research in emerging markets finance: looking to the future. Columbia Business School. 
7. Bekale, A. N., Botha, E., \& Vermeulen, J. (2015, March). Institutionalisation of Derivatives Trading and Economic Growth: Evidence from South Africa. ERSA working paper 505 . Economic Research Southern Africa (ERSA).

8. Calistru, R. A. (2012). The credit derivatives market a threat to financial stability? 8th International Strategic Management Conference (pp. 552 - 559). ELSEVIER.

9. Calistru, R. A., \& Costuleanu, C. (2011). The Impact Of Derivatives On Market Functioning. Annals Of The University Of Craiova Ecomomic Sciences .

10. Dodd, R. (2002, October). Derivatives, the Shape of International Capital Flows and the Virtues of Prudential Regulation. Discussion Paper No. 2002/93 . World Institure of Developement Economic Research (WIDER).

11. (2012-13). Economic Survey of Pakistan.

12. (2006). Feasibility Introducing Exchange traded Derivatives in Pakistan .

13. Gautam, I., \& Kavidayal, P. (2016). Evolution And Future Prospects Of Indian Derivative Market. International Journal in Management and Social Science , 4 (3).

14. Gürkaynak, R. S., \& Wolfers, J. (2005, December). Macroeconomic Derivatives An Initial Analysis of Market-Based Macro Forecasts, Uncertainty and Risk. IZA DP No. 1899 .

15. Ilyas, H. (2015, September). Research Gate. Retrieved from https://www.researchgate.net/publication/281967253.

16. Iqbal, J. (2008). Stock Market in Pakistan - An Overview.

17. Khalid, A. M. (2007). Bond Market Developments in Emerging Markets: Propsects and Challenges for Pakistan. SBP Research Bulletin , 3 (1) .

18. Khan, S. U., \& Abbas, Z. (2013). Does Equity Derivatives Trading Affect the Systematic Risk of the Underlying Stocks in an Emerging Market: Evidence from Pakistan's Futures Market. The Lahore Journal of Economics , 18 (1), 63-80.

19. Kim, Y.-K., \& Mugo-Waweru, F. (n.d.). Factors Behind ExchangeTraded Derivatives Products Success.

20. Lazový, J., \& Sipko, J. (2014). Impact of Financial Derivatives on the Real Economy. International Journal of Management Excellence , 4 (1).

21. M.Shafi, A. R., Hassan, S. S., \& Fareed, A. (2014). Impact of Derivatives on Efficiency of Stock Market: Evidence from Karachi Stock Exchange. International Journal of Scientific \& Engineering Research , 5 (7). 
22. McLean, R. D., Pontiff, J., \& Zhao, M. (2017, August). A Closer Look at the Effects of Equity Market Liberalization in Emerging Markets.

23. Mishra, B., Malik, S., \& Pore, L. (n.d.). Impact of Increased Derivatives-Trading in India on the Price-Discovery Process.

24. Naqvi, N. (2013). Capital Market and Economic Growth. Business Recorder.

25. Naz, F. (2011, January). Pakistan Equity Derivative Market. Pakistan Business Review , 844-852.

26. Pakistan equity market. (2012, December). Retrieved from www.mugheescity.com

27. Prabha, A. (., Savard, K., \& Wickramarachi, H. (2014, March). Deriving the Economic Impact of Derivatives. Milken Institute .

28. Rahman, S., \& Hassan, M. K. (2011). The Potential of Derivatives Market in Bangladesh. Journal of Economic Cooperation and Development , 32 (4), 97-144.

29. Sajjad, F., Noreen, U., \& Zaman, K. (2013). Impact of Derivatives on Financial Services Sector and Risk Management. Middle-East Journal of Scientific Research , 18 (6), 748-758.

30. Saroha, D. P., \& Yadav, D. S. (2013). Derivative market in India: Prospects \& Issues. International Multidiciplenery e-Journal .

31. Sill, K. (1997). The Economic Benefits and Risks Of Derivative Securities. Business Review . Federal Reserve Bank of Philadelphia.

32. Srivastava, D. A. (2010, September). Derivative market in India status and prospects .

33. Sundaram, R. K. (2012, September). Derivatives in Financial Market Development. Working paper . International Growth Centre.

34. Treviño, L. (2005). Development and volume growth of organized derivatives trade in emerging markets. Ensayos, XXIV (2), 31-82. 